http://jmscr.igmpublication.org/home/

ISSN (e)-2347-176x ISSN (p) 2455-0450

crossref DOI: https://dx.doi.org/10.18535/jmscr/v7i11.157

Journal Of Medical Science And Clinical Research

\title{
Aetiopathological Study of Fournier's Gangrene and Its Management
}

\author{
Authors \\ Prof. (Dr) Braja Mohan Mishra ${ }^{1}$, Dr Sandeep Mishra ${ }^{2}$, Dr Dibyajyoti Das ${ }^{3 *}$ \\ ${ }^{1}$ Prof. \& HOD, ${ }^{2}$ Senior Resident, ${ }^{3}$ Junior Resident \\ Department of General Surgery, VIMSAR, Burla, Sambalpur, Odisha, India \\ *Corresponding Author \\ Dr Dibyajyoti Das \\ Junior Resident, Dept. of General Surgery, VIMSAR, Burla, Sambalpur, Odisha, India
}

\begin{abstract}
Introduction: Fournier's Gangrene is an acute fulminating cellulitis of the scrotum which develops suddenly and often without any apparent cause. Fournier's Gangrene is a surgical emergency and can be managed by prompt diagnosis along with immediate debridement of involved necrotic tissue and institution of appropriate antibiotics therapy.

Materials \& Method: A Observational Prospective study done in VIMSAR, Burla, from nov. 2017 to oct. 2019. Total number of patient taken was 40.

Discussion: Aggressive surgical debridement following initial resuscitation with IV fluids, Proper antibiotics, analgesic can decrease the mortality of the disease.

Conclusion: Early diagnosis and prompt and better management of this emergency condition was undertaken so as to reduce the mortality and morbidity of this serious condition to a minimum.
\end{abstract}

Keywords: Fournier's Gangrene, Debridement.

\section{Introduction}

Fournier's Gangreneis an acute fulminating cellulitis of the scrotum which develops suddenly and often without any apparent cause. This idiopathic gangrene is an unusual condition in a healthy person- it is a surgical emergency and needs to be managed accordingly. Scrotum is an unlikely site of gangrene because this area of the human body is richly supplied with blood from different sources and free anastomosis occurs between those arteries. Since the areolar tissue of scrotum is lax there is a chance that due to this, spread of infection is facilitated which causes severe edema of scrotum, thus further occluding the vascular supply of the region. The epidemiology has changed from the original description in that the disease is no longer restricted to young men but it may affect a wide age range, from neonates to the very elderly. Various Predisposing factors have been identified, e.g., diabetes mellitus, steroids, immunosuppression, alcohol abuse, etc. There are certain risk factors which are of prognostic significance, e.g. the presence or absence of associated underlying disease delay in the initiation of treatment, the treatment modality, etc. In spite of extensive work on the subject and advances in anti-microbial therapy and aggressive surgical approach, the condition still carries a high mortality and should be considered a potentially 


\section{JMSCR VoI||07||Issue||11||Page 905-909||November}

lethal condition. Prompt diagnosis of this condition is critical along with immediate debridement of involved necrotic tissue and institution of appropriate antibiotic therapy. Despite aggressive modern management, the mortality rate in Fournier's gangrene may be as high as $16 \%$ to $40 \%$.

In spite of the identification and initial description of this disease by Fournier more than a hundred years ago, its various aspects like predisposing factors, causative organisms, clinical presentation, management, outcomes, etc. need further Study.

\section{Materials and Method}

Institutional ethical committee clearance and informed consent of the patients was taken before the study. 40 patients of Fournier's gangrene were studied at VSS Institute of Medical Sciences and Research, Burla, Odisha, India during Nov.2017 to Oct. 2019. Study design was Observational Prospective study

Inclusion Criteria: All the patients presenting with clinical features of Fournier's gangrene admitted to department of General surgery from November 2017 to October 2019.

Exclusion Criteria: Patient with- filarial scrotum, -infected sebaceous cyst of scrotum -gonococcal balanitis with edema

\section{Observation}

Table 1 Age Incidence

\begin{tabular}{|l|c|c|}
\hline $\begin{array}{l}\text { Age Group } \\
\text { (yrs) }\end{array}$ & $\begin{array}{c}\text { No. of } \\
\text { Patients }\end{array}$ & $\begin{array}{c}\text { Percentage \% of } \\
\text { total }(\mathbf{n = 4 0})\end{array}$ \\
\hline $00-10$ & 1 & 2.5 \\
\hline $11-20$ & 2 & 5.0 \\
\hline $21-30$ & 4 & 10.0 \\
\hline $31-40$ & 8 & 20.0 \\
\hline $51-60$ & 10 & 25.0 \\
\hline $41-50$ & 9 & 22.5 \\
\hline $61-70$ & 6 & 15.0 \\
\hline$\Rightarrow 71$ & 0 & 0.0 \\
\hline
\end{tabular}

This study consisted of 40 (forty) patients of clinically diagnosed Fournier's Gangrene admitted in the Indoor Wards of Dept. of General Surgery, VIMSAR, Burla, Sambalpur, during the period Nov. 2017 to Oct. 2019. The total number of patients admitted in the Surgery during the above period was 9030; therefore, the incidence rate of Fournier's gangrene in our hospital being 4.4297 per thousand patients admissions. Most of the patients were in the age group of 31 o 60 years, with a mean $=44.86875$ yrs $\left(+\_15.72714\right.$ yrs)

Table 2 Distribution of Cases by Socio-Economic Status

\begin{tabular}{|l|c|c|c|c|}
\hline $\begin{array}{l}\text { Socio- } \\
\text { Economic } \\
\text { Group }\end{array}$ & $\begin{array}{c}\text { No. of } \\
\text { Patients }\end{array}$ & $\begin{array}{c}\text { Percentage of } \\
\text { Total }(\mathrm{n}=40) \\
\%\end{array}$ & Habitat & $\begin{array}{c}\text { Number } \\
(\% \text { of total })\end{array}$ \\
\hline Low & 31 & 77.5 & Rural & $27(67.5)$ \\
\cline { 4 - 5 } & 9 & 22.5 & Urban & $4(10.0)$ \\
\hline \multirow{2}{*}{ Middle } & 0 & 0 & Rural & $1(2.5)$ \\
\hline \multirow{2}{*}{ High } & 0 & \multirow{2}{*}{0} & Ruran & $8(20)$ \\
\cline { 4 - 5 } & & & Urban & 0 \\
\hline
\end{tabular}

Out of the 40 patients in our study, 28 were from rural areas $(70 \%)$, whereas, 12 were from urban areas $(30 \%)$. Thirty one patients belonged to Low Socio-Economic (77.5\%), and 9 to Middle SocioEconomic Group (22.5\%). None of the patients were from High Socio-Economic Group. This table shows that persons of Low SE strata are predominantly affected with Fournier's gangrene.

Table 3(a) Predisposing Factors and Associated Conditions

\begin{tabular}{|l|c|c|}
\hline $\begin{array}{l}\text { Predisposing } \\
\text { Condition }\end{array}$ & $\begin{array}{c}\text { Number of } \\
\text { Patients }\end{array}$ & $\begin{array}{c}\text { Percentage of Total } \\
(\mathrm{n}=40) \%\end{array}$ \\
\hline Boil & 12 & 30.0 \\
\hline Abscess / Boil (large) & 6 & 15.0 \\
\hline $\begin{array}{l}\text { Minor Trauma / } \\
\text { Scratch }\end{array}$ & 9 & 22.5 \\
\hline Infections (nearby) & 5 & 12.5 \\
\hline Operative Procedures & 1 & 2.5 \\
\hline Unknown & 7 & 17.5 \\
\hline
\end{tabular}

Table-3 (b)

\begin{tabular}{|l|c|c|}
\hline Associated Condition & $\begin{array}{c}\text { Number of } \\
\text { Patients }\end{array}$ & $\begin{array}{c}\text { Percentage of Total } \\
(\mathrm{n}=40) \%\end{array}$ \\
\hline Poor Personal Hygiene & 18 & 45.0 \\
\hline Smoker & 12 & 30.0 \\
\hline Diabetes Mellitus & 11 & 27.5 \\
\hline Alcoholic & 10 & 25 \\
\hline Hypertension & 9 & 22.5 \\
\hline Infections & 3 & 7.5 \\
\hline
\end{tabular}

In 18 cases, boil / abscess were the initiating factor; minor trauma / scratch ware implicated in 9 cases and no cause could be determined in 7 cases. 
Table- 4 Clinical Features and Lab Work-up Results Association

\begin{tabular}{|c|c|c|c|}
\hline & Parameter & $\begin{array}{c}\text { Number of Patients } \\
(\mathrm{n}=40)\end{array}$ & Percentage $\%$ \\
\hline \multirow[t]{3}{*}{ Clinical Features } & Fever with Tachycardia & 24 & 60.0 \\
\hline & Septicaemia at Presentation & 10 & 25.0 \\
\hline & Foul / Fetid Odour from wound & 21 & 52.5 \\
\hline \multirow[t]{4}{*}{ Lab Results } & $\mathrm{Hb} \%$ & 18 & 45.0 \\
\hline & PMN\% & 31 & 77.5 \\
\hline & FBS / RBS & 17 & 42.5 \\
\hline & 仓 Sr. Cr/ Bl Urea & 19 & 47.5 \\
\hline
\end{tabular}

Majority of the cases had systematic manifestations of infection, namely, fever, malaise, tachycardia, prostration. Fever being the commonest, it was present in 24 out of 40 patients, all patients with fever also complained of malaise and body ache. General feeling of ill health was present in all the cases. Ten of patients admitted were insepticaemic / hypovolemic shock at the time of presentation, and needed vigorous resuscitation with IV fluids, antibiotics and blood transfusion. Most of the patients (29 of $40=$ 72.5\%) had Leucocytosis, i.e.., a total leukocyte count greater than 9060 per cu.mm. raised PMN count $(\mathrm{N}=40-70 \%)$ was present in all patients including 2 with normal leukocyte counts (31 of 40 patients $=75 \%$ ). Eighteen of the patients were anemic at time of admission and most of them required blood transfusions during course of their management. Foul smelling fetid odor was noted in 21 of the 40 patients.

Table 5 Organisms Isolated / Cultured from Pus in wounds

\begin{tabular}{|c|c|c|c|c|}
\hline Group & Organism Isolated & $\begin{array}{c}\text { Number of } \\
\text { cases }(n=40)\end{array}$ & Percentage $\%$ & \\
\hline \multirow{2}{*}{ Gram Positive } & Staphylococcus (alone) & 5 & 12.5 & \multirow{2}{*}{$8(20.0 \%)$} \\
\hline & Streptococcus (alone) & 3 & 7.5 & \\
\hline \multirow{6}{*}{ Gram Negative } & E coli (alone) & 5 & 12.5 & \multirow{6}{*}{$19(47.5 \%)$} \\
\hline & Pseudomonas & 3 & 7.5 & \\
\hline & Proteus & 4 & 10.0 & \\
\hline & Klebsiella & 2 & 5.0 & \\
\hline & Citrobacter & 3 & 7.5 & \\
\hline & Acinetobacter & 2 & 5.0 & \\
\hline \multirow{2}{*}{ Mixed Growth } & $\begin{array}{l}\text { Staphylococcus \& } \\
\text { Streptococcus }\end{array}$ & 1 & 2.5 & \multirow[t]{2}{*}{$3(7.5 \%)$} \\
\hline & E coli \& Staph / Strep & 2 & 5.0 & \\
\hline None & No Growth & 10 & 25.0 & $10(25.0 \%)$ \\
\hline
\end{tabular}

Most common isolates from patients in our study were Staphylococcus (alone) or E coli (alone). Predominant were other Gram Negative organisms, especially of Enterobacteriaceae family. No growth occurred in 10 samples on culture. Clostridium group was not isolated in any case because of lack of facilities for anaerobic culture.

Table-6(a) Management \& Time Relationship of various Events

\begin{tabular}{|l|c|c|c|}
\hline Event & Mean Duration (days) & Median (Days) & Std. Dev. \\
\hline Appearance of gangrene after onset of illness & 5.325 & 3 & 6.844004 \\
\hline Duration of systemic symptoms after debridement & 3.5 & 3.5 & 1.132277 \\
\hline Duration of Hospital Stay & 12.875 & 12 & 6.58743 \\
\hline
\end{tabular}


Table-6(b) Treatment offered

\begin{tabular}{|l|c|c|}
\hline Mode of treatment & Number of Patients $(\mathbf{n}=\mathbf{4 0})$ & Percentage \% \\
\hline Debridement only (wide) & 7 & 17.5 \\
\hline Secondary Suturing & 26 & 65.0 \\
\hline Secondary Suturing + Skin Grafting & 7 & 17.5 \\
\hline
\end{tabular}

Table-6(C) Duration of Hospital Stay and Outcome

\begin{tabular}{|l|c|c|c|c|}
\hline $\begin{array}{l}\text { Days of } \\
\text { Hospital Stay }\end{array}$ & $\begin{array}{c}\text { Number of Patients } \\
(\mathbf{n = 4 0})(\%)\end{array}$ & Improved & $\begin{array}{c}\text { Referred/ } \\
\text { LAMA }\end{array}$ & Died \\
\hline$<=7$ & $7(17.5)$ & 1 & 0 & 6 \\
\hline 8 to 14 & $22(55.0)$ & 19 & 3 & 0 \\
\hline 15 to 21 & $7(17.5)$ & 7 & 0 & 0 \\
\hline 22 to 27 & $2(5.0)$ & 2 & 0 & 0 \\
\hline =>28 & $2(5.0)$ & 2 & 0 & 0 \\
\hline Total & 40 & 31 & $3(7.5 \%)$ & $6(15 \%)$ \\
\hline
\end{tabular}

Average duration of systematic toxic symptoms after primary wound excision and debridement was 3.5 days $(++1.132277)$ in two cases with extensive scrotal skin loss, their testes could not be placed in the scrotal sac - hence, their testes were transpositioned in the subcutaneous plane on either side of the upper thigh and skin sutured in the midline in the perineum.

\section{Discussion}

Fournier's gangrene was recognized as a separate disease entity more than 100 years ago, but exact aetiology of the disease is still unknown. As time and technology have progresses, various predisposing factors and aetiologic factors have begun to emerge to explain this rather serious surgical emergency. The epidemiology has changed from the original description in that the disease is no longer restricted to young men, but may affect individuals of a wide age- range. In our study of 40 (forty) patients of Fournier's gangrene, the age range was between 9 months and 70 years. Most of the patients (27-67.5\%) were between the age -group of 31 to 60 years. In our study, 31 out of 40 patients belonged to low socio-economic group, 9 were of middle and none from high socio-economic group. In our study, we found that in about $22.5 \%$ (9) of cases, minor trauma or scratch was responsible for the development of the disease condition. In about $45 \%$ of the cases, boil/ abscess were responsible and no cause was found in $17.5 \%$ (7) of the cases. In Fournier's original description too, the disease was of Idiopathic origin. In our series, we found 11 out of 40 patients of Fournier's gangrene having Diabetes Mellitus as a co-morbid condition. In our study bacteriological analysis of pus sample from wounds showed the predominance of Gram negative organisms (E Coli, Citrobacter, Proteus, Pseudomonas, etc.) in the wound (19 cases of $40-47.5 \%$ ), as compared to Gram positive organisms (Staphylococcus, Streptococcus) (8 cases- 20.0\%); whereas, 10 $(25.0 \%)$ samples failed to show up any organisms in the pus specimen. Although anaerobic culture could not be done in our study, the clinical presentation of none of our cases showed features of gas gangrene. Neither were toxic symptoms as severe in gas gangrene, nor were there any presence of gas in the scrotum. Systemic symptoms, e.g.; fever with chills, tachycardia and dehydration were also present in 24 to 40 cases $(60 \%)$. General feeling of ill health was present in almost all the cases. In our study, the involvement with Fournier's gangrene of whole or most part of the scrotum was most commonly seen (26 of 40 cases - 65\%), partial involvement seen in 12 of 40 cases $(30 \%)$.In our series, we have seen complete 


\section{JMSCR Vol||07||Issue||11||Page 905-909||November}

recovery in most of the cases (31 of 40-77.5\%), without excessive morbidity or mortality; 6 of the 40 patients $(15 \%)$ died during course of management in the hospital, due to various reasons and 3 were referred to higher center or left against medical advice (LAMA). In many of the earlier cases reports, a typical mortality range of 25 to $40 \%$ was depicted, but in our study, it was $15 \%$ (6 of 40 patients died). The lower mortality rate was due to aggressive and prompt management of this emergency condition with high grade antibiotics and wide debridement, coupled with daily dressings

\section{Conclusion}

The diagnosis of Fournier's gangrene is mainly based upon clinical grounds and there should be high index of suspicion. The basic treatment of this disease involves early debridement of all nonviable tissues after aggressive resuscitation, early antibiotic treatment, limitation and / or abolition of any local / general infective / immunesuppressive processes present in the patient and occasional anatomic reconstruction.

\section{Reference}

1. Sorensen mo. Krieger J.N. Fournier's Gangrene: epidemiology and outcomes in the general US population UroInt 2016; 97:249.59

2. Hagedorn JC, Wessels H. A contemporary update on Fournier's Gangrene. Nat. Rev. Uro 2017:14:205-14

3. Tang LM, Su YJ, Lai YC. The Evaluation of Microbiology \& Prognosis of Fournier's Gangrene in past five years : Springor plus 2015; 4:14

4. Anton Pacheco Sanchez J; Angulo Gomez S; Canonovillo I; Gomez Fraile A (1994) : Fournier's Gangrene secondary to Anorectal trauma. Actas. Urol. Esp. 18(4): 302-4

5. Ali MZ (2004): Fournier's Gangrene - A rare complication of hydrocele aspiration. J Coll Physicians Surg Pak. 14(5) : 304-5
6. Archer MI (1986): Diabetes Mellitus and Fournier's Gangrene. Diabe. Med. 3(3): 268-9

7. Badejo A (1985): Management of Scrotal gangrene. Trop. Geogr. Ned. 37(4): 337-42

8. Basoglu M, American Surgeon, 63(11): 1019-21. 1997 Nov.

9. Bejanga BL. Fournier's Gangrene. BrF Urol: 1979, $51: 312-16$

10. Bertoglio JS: Ratlif RK (1943) : Urol. Cut Rev. 47, 352. 